GRASAS Y ACEITES 69 (2)

April-June 2018, e256

ISSN-L: 0017-3495

https://doi.org/10.3989/gya.0110181

\title{
Chemical characterization of commercial and single-variety avocado oils
}

\author{
G.D. Fernandes ${ }^{\mathrm{a}, \bigotimes}$, R.B. Gómez-Coca ${ }^{\mathrm{b}}$, M.C. Pérez-Camino ${ }^{\mathrm{b}}$, W. Moreda ${ }^{\mathrm{b}}$ and D. Barrera-Arellano ${ }^{\mathrm{a}}$ \\ ${ }^{\mathrm{a}}$ Fats and Oils Laboratory, Department of Food Technology, University of Campinas, Bertrand Russell, 13081-970, \\ Campinas, Brazil. \\ ${ }^{\mathrm{b}}$ Department of Characterization and Quality of Lipids, Instituto de la Grasa-CSIC, Campus of University Pablo de Olavide, \\ Building 46, E-41013-Seville, Spain. \\ ${ }^{\square}$ Corresponding author: gabrieldfcac@hotmail.com
}

Submitted: 19 January 2018; Accepted: 08 March 2018

SUMMARY: This work aimed to determine the major and minor compounds of avocado oils. Mono-varietal oils from the Bacon, Fuerte, Hass, and Pinkerton cultivars were obtained by means of an Abencor ${ }^{\circledR}$ system, while commercial oils from Brazil, Chile, Ecuador and New Zealand were purchased locally. The content of triacylglycerols, fatty acids, aliphatic and terpenic alcohols, desmethyl- methyl- and dimethyl-sterols, squalene and tocopherols were determined. The main triacylglycerols were those with ECN48. In addition, the oleic, palmitic and linoleic acids prevailed. Desmethyl-sterols were the principal minor compounds. Low amounts of aliphatic and terpenic alcohols were also found. Squalene concentrations were higher in Bacon, Fuerte and Pinkerton oils than in the other oils. The most abundant tocopherol was $\alpha$-tocopherol. Partial least squares discriminant analysis made it possible to express the differences among the samples. To summarize, this work brings a different approach to the complete characterization of avocado oil.

KEYWORDS: Avocado oils; Chemical characterization; Commercial oils; Mono-varietal oils; Persea americana Mill.

RESUMEN: Caracterización química de aceites monovarietales y comerciales de aguacate. El objetivo de este trabajo ha sido la determinación los componentes mayoritarios y minoritarios del aceite de aguacate. Los aceites monovarietales de las variedades Bacon, Fuerte, Hass y Pinkerton se obtuvieron mediante un sistema Abencor ${ }^{\circledR}$, mientras que los aceites comerciales de Brasil, Chile, Ecuador y Nueva Zelanda se compraron en la localidad. Se determinó el contenido de triacilgliceroles, ácidos grasos, alcoholes alifáticos y terpénicos, desmetilmetil, metil y dimetil esteroles, escualeno y tocoferoles. Los principales triacilgliceroles fueron aquellos con ECN48. Además, prevalecieron los ácidos grasos oleico, palmítico y linoleico. Los desmetil esteroles fueron los compuestos minoritarios principales. También se encontraron bajas cantidades de alcoholes alifáticos y terpénicos. Las concentraciones de escualeno fueron más altas en los aceites de las variedades Bacon, Fuerte y Pinkerton que en las otras variedades. El tocoferol más abundante fue el $\alpha$-tocoferol. El análisis discriminante de mínimos cuadrados permitió expresar las diferencias entre las muestras. En resumen, este trabajo aporta un enfoque diferente a la caracterización completa del aceite de aguacate.

PALABRAS CLAVE: Aceite de aguacate; Aceites comerciales; Aceites monovarietales; Caracterización química; Persea americana Mill.

ORCID ID: Fernandes GD https://orcid.org/0000-0001-6099-3225, Gómez-Coca RB https://orcid.org/0000-00026925-8232, Pérez-Camino MC https://orcid.org/0000-0001-7652-9582, Moreda W https://orcid.org/0000-0001-89066548, Barrera-Arellano D https://orcid.org/0000-0002-8217-8392

Citation/Cómo citar este artículo: Fernandes GD, Gómez-Coca RB, Pérez-Camino MC, Moreda W, Barrera-Arellano D. 2018. Chemical characterization of commercial and single-variety avocado oils. Grasas Aceites 69 (2), e256. https:/l doi.org/10.3989/gya.0110181

Copyright: (02018 CSIC. This is an open-access article distributed under the terms of the Creative Commons Attribution 4.0 International (CC BY 4.0) License. 


\section{INTRODUCTION}

Avocado oil is extracted from the pulp of Persea americana fruits. In the fruit, the oil is stored as a single oil droplet in the idioblast cells, which are dispersed in the mesocarp (pulp). The idioblast wall structure is very complex, and it is basically composed of two cellulose layers separated by a suberin layer (Platt and Thomson, 1992). This morphology hampers oil extraction. Studies regarding nutritional effects of avocado oil consumption have been focused on its healthy characteristics, which are mainly related to its high content in monounsaturated fatty acids such as oleic acid (Lerman-Gaber et al., 1994).

According to FAO, Mexico is the world's largest producer of avocados. In 2014, this country produced 1.52 million tons of avocado fruits, around $30 \%$ of the world stock (FAOSTAT, 2014). However, the avocado oil industry grows slowly because it is only a side-industry of the fresh-fruit business.

Taxonomically, the P. americana specie is separated into three distinct races, commonly known as Mexican, Guatemalan and West Indian (Mohameed et al., 1997). Over many years of cultivation, the crossing of the three races has resulted in the development of a large variety of avocado cultivars; however, due to differences in their oil contents, only a few of them are used as industrial oil sources (Tango et al., 2004). The Hass (from the Guatemalan race) and Fuerte (from the crossing between Guatemalan and Mexican races) varieties are commonly utilized for oil extraction, with oil contents of around 30\%. Among other cultivars with potential application in the oil industry, we can cite the Pinkerton and Bacon varieties, both coming from Guatemalan and Mexican race crossing (Mohameed et al., 1997; Ashworth and Cleeg, 2003).

Although several methods have been proposed for obtaining avocado oil, including enzyme, solvent and supercritical fluid extraction (Freitas et al., 1998; Moreno et al., 2003; Botha and McCrindle, 2003; Ortiz et al., 2004), the market trend toward more 'natural' oils has forced them aside. At present, cold pressed 'virgin' oil is preferred by consumers. In this way, the industrial extraction of avocado oil has become quite similar to that of olive oil, with the main differences related to skin removal, stoning and malaxation. In the case of avocado oil extraction, this last step is conducted at higher temperature $\left(45^{\circ} \mathrm{C}\right)$ and during longer periods of time $(>60 \mathrm{~min})$ than for olive oil extraction. These changes are necessary due to the obvious differences between avocados and olive fruits. The structure of the idioblast cells also makes oil extraction more difficult than in the case of the olive mesocarp. Finally, the ultimate pulp-water-oil separation is done through two centrifugation steps by means of decanting and polish centrifuges (Wong et al., 2010).
The fatty acid composition of avocado oil has been reported in several studies, describing oleic acid $(\mathrm{C} 18: 1 \omega 9)$ as the main one. This fact has been used as support for studies that aim to prove the beneficial health effects of this oil, such as a reduction in effects from diabetes, oxidative stress on the mitochondrial membrane and cardiovascular disease markers (Ortiz-Avila et al., 2013; CarvajalZarrabal et al., 2014).

In order to achieve the standardization of avocado oil, Woolf et al., (2009) proposed a classification according to processing and quality parameters: 'extra virgin', with high quality and low sensory defects; 'virgin', with low quality features and some sensory defects; 'pure', a kind of refined avocado oil; and 'blend', when the oil is mixed with other vegetable oils. These authors suggested a typical fatty acid (FA) profile composed of palmitic (C16:0) 10-25\%, palmitoleic (C16:1) 2-8\%, stearic (C18:0) 0.1-1,5\%, oleic (C18:1) 60-80\%, linoleic (C18:2) 7-20\%, and linolenic (C18:3) 0.2-1\% acids. In addition, the tocopherol content was established to be between $70-190 \mathrm{mg} \cdot \mathrm{kg}^{-1}$. However, in our bibliographical search we found other ranges for these identity parameters: palmitic at $10.0-35.2 \%$; palmitoleic at $2.8-16.1 \%$; stearic at $0.2-1.5 \%$; oleic at $36.9-74 \%$; linoleic at $6.1-21.2 \%$; and linolenic at $0.3-2.1 \%$, together with tocopherols at $130-250$ $\mathrm{mg} \cdot \mathrm{kg}^{-1}$ (Tango et al., 1972; Werman and Neeman, 1987; Martínez-Nieto et al., 1992; Moreno et al., 2003; Tango et al., 2004; Salgado et al., 2008; Rueda et al, 2014; Rueda et al, 2016). Other features have also been cited such as the sterol composition and content, with $\beta$-sitosterol as the main sterol (71.8$93.05 \%$ ) with low amounts of clerosterol, avenasterol, campesterol and sitostanol, along with a triacylglycerol (TAG) profile where OOP, OOO and OOL (O, oleic acid; P, palmitic acid; L, linoleic acid) were the most abundant species (Hierro et al., 1992; Martínez-Nieto et al., 1992; Salgado et al., 2008). Nevertheless, a comprehensive study involving the composition of the major and minor compounds of avocado oil has not been carried out.

Therefore, the aim of this work was to characterize mono-varietal avocado oils from the Bacon, Fuerte, Hass and Pinkerton cultivars as well as commercial avocado oils from Brazil, Chile, Ecuador and New Zealand. This approach greatly contributes to the knowledge about the chemical composition of such oil, supporting the establishment of legislative standards.

\section{MATERIALS AND METHODS}

\subsection{Chemicals}

Acetone, diethyl ether, hexane, propionitrile, and tetrahydrofuran (THF) were supplied by VWR International (West Chester, PA). Potassium 
hydroxide was from Panreac (Montcada I Reixac, Barcelona, Spain). Silica-solid phase extraction (Si-SPE) cartridges were from Varian (EA Middelburg, The Netherlands). Standards of fatty acid methyl esters (FAME, Supelco 37 component mix), 5- $\alpha$-cholestan-3 $\beta$-ol, squalane and n-eicosanol were from Sigma-Adrich Co. (St. Louis, MO). Hexamethyl disilazane, pyridine, trimethyl chloroxilane and standards of tocopherols were from Merck (Merck Group, Darmstadt, Germany). All chemical reagents were at least analytical grade.

\subsection{Samples}

Mature fruit samples of the Bacon, Fuerte, Hass and Pinkerton cultivars were provided by Instituto de Hortofruticultura Subtropical y Mediterránea La Mayora (IHSM-CSIC, Málaga-Spain). The avocado fruits arrived at the laboratory the day after the harvest under perfect phytosanitary conditions. The oil content was extracted two days after the fruits arrived at the laboratory at the Instituto de la Grasa (Sevilla-ES), by means of an Abencor ${ }^{\circledR}$ system, described in Section 2.4. Throughout the storage time, the fruits were kept at room temperature and no changes were noted. Commercial avocado oil samples from the Hass variety were obtained from common and commercial brands in a local grocery store from Brazil, Chile (named 'Chile A' and 'Chile B'), Ecuador, and New Zealand. Four bottles with $500 \mathrm{~mL}$ of each sample were purchased from the same lot. They were taken to the laboratory, at the Instituto de la Grasa (Sevilla-ES), by air mail, and properly stored at $4{ }^{\circ} \mathrm{C}$ until analysis. For ethical reasons no commercial brand will be cited in this paper.

\subsection{Extraction of mono-varietal avocado oils}

For each extraction, $500 \mathrm{~g}$ mature avocados, without seeds, were milled in a knife mill and the paste was taken for extraction by means of an Abencor ${ }^{\circledR}$ system malaxer, and centrifuge (MC2 Ingenieria Sistemas, Seville, Spain) followed by an additional centrifugation step. Malaxation was carried out below $40^{\circ} \mathrm{C}$ for $40 \mathrm{~min}$, with talc addition $\left(\sim 10 \mathrm{~g} \cdot 100 \mathrm{~g}^{-1}\right.$ paste $)$. Distilled water, $\left(20 \mathrm{~mL} \cdot 100 \mathrm{~g}^{-1}\right.$ paste) was added after 10 min of starting the malaxation process. The first centrifugation was carried out in the Abencor ${ }^{\circledR}$ system centrifuge at $3000 \mathrm{rpm}$ during $60 \mathrm{~s}$. The paste was then spilt out and the liquid phase was further centrifuged in a bench centrifuge (5000 rpm, $10 \mathrm{~min})$. The oil obtained was filtered and stored at $4{ }^{\circ} \mathrm{C}$ until analysis.

\subsection{Chemical Characterization}

Fatty acid composition. The fatty acid (FA) composition was determined as the composition of fatty acid methyl esters by gas chromatography
(GC), according to the IUPAC Standard Methods 2.301 and 2.302 (IUPAC, 1987). Transesterification of the oils was carried out with a $2 \mathrm{~N}$ methanolic $\mathrm{KOH}$ solution. The chromatographic analysis was done using an Agilent 5890 GC system (Palo Alto, CA) equipped with split injector (1:50 split ratio), automated sampler ( $1 \mu \mathrm{L}$ injections), polar capillary column SPTM-2380 (poly (90\% biscyanopropyl- $10 \%$ cyanopropyl-phenyl) siloxane, $60 \mathrm{~m} \times 0.25$ $\mathrm{mm}$ internal diameter (i.d.) $\times 0.20 \mu \mathrm{m}$ film thickness, SUPELCO, Bellefonte, PA), and flame ionization detector (FID). Hydrogen was used as carrier gas at a flow rate of $1.0 \mathrm{~mL} \cdot \mathrm{min}^{-1}$. The detector and injector temperatures were 225 and $250{ }^{\circ} \mathrm{C}$, respectively. The initial oven temperature was $180^{\circ} \mathrm{C}$, and the temperature gradient was from 180 to $220^{\circ} \mathrm{C}$ at $3{ }^{\circ} \mathrm{C} \cdot \mathrm{min}^{-1}$. Data were described as the fatty acid profile by peak area normalization, and expressed as percentage of the total area of the identified fatty acids. Peak identification was made by comparing their retention times with those of the corresponding FAME mixture of standards, as well as with the standard chromatogram provided by the method.

Triacylglycerol composition. This determination was made according to Moreda et al. (2003). Oil samples were purified using a Si-SPE cartridge. The cartridge was washed under gravity with $6 \mathrm{~mL}$ hexane. After that, a solution of the oil $(0.12 \mathrm{~g})$ in $0.5 \mathrm{~mL}$ hexane was added. The solution was pulled through the cartridge and then eluted with $10 \mathrm{~mL}$ of a hexane-diethyl ether $(87: 13 \mathrm{v} / \mathrm{v})$ solution. The eluted solvents were evaporated to dryness under reduced pressure at room temperature. The residue was dissolved in $2 \mathrm{~mL}$ acetone. For TAG analysis this solution $(10 \mu \mathrm{L})$ was injected directly using the auto-sampler (508 system) in a RP-HPLC system. The separations were done on a Merck Li-Chrospher 100 RP-18 column $(250 \mathrm{~mm} \times 4 \mathrm{~mm}$ i.d. $\times 4 \mu \mathrm{m}$ particle size) thermostated at $20^{\circ} \mathrm{C}$. The liquid chromatograph (Beckman Coulter, Fullerton, CA) was equipped with a pumping unit (118 solvent module) and propionitrile was used as the mobile phase at a flow rate of $0.6 \mathrm{~mL} \cdot \mathrm{min}^{-1}$. Detection was done with a PerkinElmer 200 RI detector (PerkinElmer, Waltham, MA). TAG peak assignment was carried out by means of comparison with the elution time and the standard chromatograms described by the authors. Data were processed by peak area normalization and expressed as TAG percentages. TAG were grouped according to their equivalent carbon number $(\mathrm{ECN})$, with $\mathrm{ECN}$ being the number of carbons from the fatty acids of the TAG molecule minus two times the number of double bonds.

Sterol composition and aliphatic alcohols. Sterols and aliphatic alcohols are minor components of the oil unsaponifiable fraction. Therefore, it is advisable to remove the saponifiable compounds previously in order to get better analytical results. In this line, we followed the methodology proposed by the 
International Olive Council (IOC, 2013; IOC, 2015). In short, samples of $5 \mathrm{~g}$ of oil were saponified under reflux with $50 \mathrm{~mL}$ of a $2 \mathrm{~N}$ ethanolic $\mathrm{KOH}$ solution for $1 \mathrm{~h}$. The unsaponifiable compounds were then extracted with diethyl ether $(3 \times 80 \mathrm{~mL})$ and the organic phase was neutralized by means of washing it with distilled water. The residue (unsaponifiable matter) was fractionated by silica TLC using plates impregnated with potassium hydroxide. The plate was developed twice with a mixture of hexane:diethyl ether $(65: 35, \mathrm{v} / \mathrm{v})$. Three fractions were obtained: desmethyl-sterols, methyl-sterols together with aliphatic alcohols, and dimethyl-sterols. Each of them was scratched off and extracted with hot chloroform and diethyl ether. The solution was evaporated until dryness, derivatized with $500 \mu \mathrm{L}$ of the 1:3:9 (v/v/v) trimethyl chloroxilane:hexamethyl disilazane:pyridine admixture, and analyzed by GC. The gas chromatograph (Agilent 6890N, Agilent, Santa Clara, CA) was equipped with a fused silica low-polarity capillary column (DB5-HT, poly (5\% diphenyl- $95 \%$ dimethyl) siloxane, $30 \mathrm{~m} \times 0.25 \mathrm{~mm}$ i.d. $\times 0.2 \mu \mathrm{m}$ film thickness, Agilent Technologies), and FID. The oven program for the determination of the desmethyl-sterols (first fraction) was set isothermally at $260^{\circ} \mathrm{C}$, with a $1: 50$ split ratio. Hydrogen was used as carrier gas at a flow rate of $1 \mathrm{~mL} \cdot \mathrm{min}^{-1}$. For the second and the third fractions, a temperature gradient was applied starting at $220^{\circ} \mathrm{C}(2 \mathrm{~min})$ until $295^{\circ} \mathrm{C}$ at $2{ }^{\circ} \mathrm{C} \cdot \mathrm{min}^{-1}$. The temperature of the injector and detector was $300^{\circ} \mathrm{C}$. The quantitative determination was done using $\alpha$-cholestanol as the internal standard for desmethyl-sterols and n-eicosanol for aliphatic alcohols, methyl- and dimethyl-sterols. Data were always expressed in $\mathrm{mg} \cdot \mathrm{kg}-1$ as the total of each compound class, and the profile of each class was described as the percentage of each compound within the class, according to the method recommendation. Peak identification was performed by relative retention time calculations and comparison with the chromatogram described in each method.

Squalene. The procedure was derived from that published previously (Lanzón et al., 1995; GómezCoca et al., 2015): $0.04 \mathrm{~g}$ oil and $40 \mu \mathrm{L}$ internal standard $\left(5 \mathrm{mg} \cdot \mathrm{mL}^{-1}\right.$ squalane) were dissolved in $1 \mathrm{~mL}$ hexane and saponified at room temperature with $200 \mu \mathrm{L} 2 \mathrm{~N}$ methanolic KOH. Two phases appeared, the upper phase (hexane) was transferred to a new vial and washed with an ethanol:water $1: 1, \mathrm{v} / \mathrm{v}$, solution. In other words, $400 \mu \mathrm{L}$ of this solution were added to the hexane phase, mixed by pipetting, and again two phases appeared. The upper phase was transferred to a new vial, and the washing procedure was carried out two more times. After that, $1 \mu \mathrm{L}$ of the supernatant was analyzed by GC. GC analyses of squalene were carried out with an Agilent 6890N Gas Chromatograph equipped with an Agilent 7683B Automatic Liquid Sampler and FID.
The acquisition of data was done with the Agilent Chem Station for the GC System program. The conditions for the GC assays were: DB5-HT column (5\% diphenyl- 95\% dimethylpolysiloxane; $30 \mathrm{~m}$ $\times 0.25 \mathrm{~mm}$ i.d. $\times 0.10 \mu \mathrm{m}$ film; Agilent Technologies), $1.0 \mu \mathrm{L}$ injection volume, with hydrogen carrier gas at $0.8 \mathrm{~mL} \cdot \mathrm{min}^{-1}$ and 20:1 split injection. The oven was set at $250{ }^{\circ} \mathrm{C}$ for 10 minutes. The injector and detector temperatures were $300{ }^{\circ} \mathrm{C}$ and $345^{\circ} \mathrm{C}$, respectively. The quantitative evaluation of squalene was carried out using squalane as internal standard, and the data expressed in $\mathrm{mg} \cdot \mathrm{kg}^{-1}$. Peaks were identified according to relative retention times together with comparison with the standard chromatogram described in the method.

Tocopherols. Tocopherols were determined according to the IUPAC Standard Method 2.432 (IUPAC, 1987). Oil samples were diluted in hexane $\left(10 \mathrm{mg} \cdot \mathrm{mL}^{-1}\right)$ and directly injected into a liquid chromatograph fitted with a Si-column $(250 \mathrm{~mm} \times$ $4 \mathrm{~mm}$ i.d. $\times 4 \mu \mathrm{m}$ particle size) The elution solvent was a hexane:2-propanol $(99: 1, \mathrm{v} / \mathrm{v})$ mixture at a flow rate of $1 \mathrm{~mL} \cdot \mathrm{min}^{-1}$. Detection was done by fluorescence (RF-10AXL Shimadzu fluorescence detector, Shimadzu, Kyoto, Japan), setting excitation and emission at $\lambda=290$ and $\lambda=330 \mathrm{~nm}$, respectively. For quantitative determinations, a calibration curve was performed by mean of injections of tocopherol standards at concentrations between $4-6 \mu \mathrm{g} \cdot \mathrm{mL}^{-1}$ in hexane and the data corresponding to each tocopherol compound was expressed in $\mathrm{mg} \cdot \mathrm{kg}^{-1}$. The retention time of the standards was used for the qualitative analysis.

Stigmastadienes. Stigmastadienes were determined only in the commercial samples in order to check the presence of refined oils. An IOC method was used for this determination (IOC, 2001). Thus, $20 \mathrm{~g}$ oil and $1 \mathrm{~mL}$ internal standard solution (3,5-cholestadien, $20 \mu \mathrm{g} \cdot \mathrm{m}^{-1}$ ) were saponified under reflux with $75 \mathrm{~mL}$ alcoholic $\mathrm{KOH}\left(10 \mathrm{~g} \cdot 100 \mathrm{~g}^{-1}\right)$ for 30 min. The unsaponifiable matter was then extracted with hexane $(2 \times 100 \mathrm{~mL})$, and the organic extract was washed with an ethanol-water $(1: 1)$ solution until neutral $\mathrm{pH}$. The solvent was then evaporated to dryness in a rotary evaporator at $30^{\circ} \mathrm{C}$. After this preparation, the residue (unsaponifiable matter) was fractionated on a silica column using hexane as the mobile phase. The first eluate $(30 \mathrm{~mL})$ was discarded and the following one $(40 \mathrm{~mL})$ collected, dried and injected into the chromatograph. The GC system used was an Agilent 6890N Gas Chromatograph equipped with an Agilent 7683B Automatic Liquid Sampler and FID. The parameters for the GC assays were: DB5-HT column (5\% diphenyl- 95\% dimethylpolysiloxane; $30 \mathrm{~m} \times 0.25 \mathrm{~mm}$ i.d. $\times 0.10$ $\mu \mathrm{m}$ film; Agilent Technologies), $1.0 \mu \mathrm{L}$ injection volume, hydrogen carrier gas at $1 \mathrm{~mL} \cdot \mathrm{min}^{-1}$ and $15: 1$ split injection. The oven temperature program was: $235{ }^{\circ} \mathrm{C}$ for 6 minutes, then raised at $2{ }^{\circ} \mathrm{C} \cdot \mathrm{min}^{-1}$ up 
to $285^{\circ} \mathrm{C}$. The injector and detector temperatures were $300{ }^{\circ} \mathrm{C}$ and $320^{\circ} \mathrm{C}$, respectively. The quantitative evaluation of 3,5-stigmastadien was carried out using 3,5-cholestadiene as internal standard. Data acquisition was done with the Agilent Chem Station for the GC System program. Data were expressed in $\mathrm{mg} \cdot \mathrm{kg}^{-1}$. Peak identification was conducted by retention time calculation based on the internal standard.

\subsection{Statistical analysis}

A multivariate statistical analysis was performed with the complete information from the chemical characterization. The tables of data were saved as .csv files and uploaded onto the Metaboanalyst 3.0 web-based tool (Xia et al., 2012). A partial least square discriminant analysis (PLS-DA) was performed in order to express graphically and in a multivariate way the relationships among the samples. A range scaling (mean-centered and divided by the value range of each variable) was used to make the features more comparable.

In order to select the most important features for sample grouping, we used the variable importance in projection (VIP-score) calculation for the component 1 . We plotted the VIP score for the ten most important features to distinguish the sample.

It is important to clarify that we used the PLS-DA as a multivariate statistic tool to represent the relationships among the full chemical compositions of the samples. We did not use this tool to create a mathematical model to classify samples, since we believe that more studies must be done on different crops, growing places, ripening stages and shelf life to create a valid model.

\section{RESULTS AND DISCUSSION}

\subsection{Major compounds, fatty acids and triacylglycerol profiles}

The FA profile is the most common parameter for oil characterization. It is widely described in many books and in the legislation. Table 1 shows the FA profile of all avocado oil samples. As expected, the

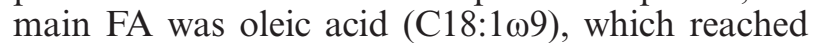
the highest concentration in the Fuerte cultivar $(64.62 \pm 0.20 \%)$. In contrast, the lowest oleic acid presence was found in the Brazilian commercial avocado oil $(45.18 \pm 0.10 \%)$. The $\omega 7$ oleic acid isomer was also observed $(7.87 \pm 0.55 \%-10.08 \pm 0.32 \%)$. Palmitic acid was the second most abundant FA, with a range between $11.64 \pm 0.13 \%$ (Chile A) and $21.05 \pm 0.06 \%$ (Brazil). Linoleic acid (C18:2) fluctuated between $8.25 \pm 0.02 \%$ in Pinkerton and $16.50 \pm 0.04 \%$ in Chile B; while palmitoleic acid

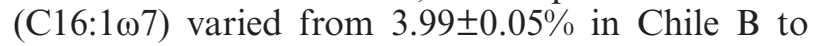
$11.41 \pm 0.02 \%$ in Brazil. The $\omega 9$ and $\omega 11$ isomers of palmitoleic acid were also detected. However, the $\omega 7$ isomer was always above $91 \%$ of the sum of the three of them. Another important characteristic is

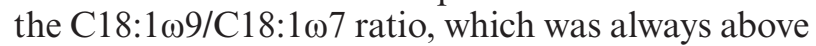
5. The presence of $\mathrm{C} 18: 1$ and C16:1 isomers ( $\omega 7, \omega 9$ and $\omega 11)$ in avocado oil is described in this work for the first time. Very low amounts $(<0,05 \%)$ of transfatty acids were detected, and they were considered irrelevant for the characterization of this vegetable oil.

All results obtained in the FA composition are within the ranges already described for avocado oil and cited in the Introduction. Nonetheless, looking at the quality standards proposed by Woolf et al. (2009) some results do not match with those described in this work. The Brazilian sample stands out due to three parameters (oleic, palmitoleic, and stearic acid contents); while Chile $\mathrm{A}$ and $\mathrm{B}$ are different as far as linolenic and stearic acids are concerned. On the other hand, Ecuador, Fuerte and Pinkerton samples differed from the published data due to their stearic acid contents. Therefore, since the samples are in accordance with other studies and some of the parameters measured for some of the mono-varietal samples are even out of the established ranges, it is possible to consider the need for more comprehensive studies and probably to modify the standard table.

Another important observation is that the fatty acid profiles obtained for these avocado oil samples were quite similar to those described for other vegetable oils, such as olive oils and nut oils (IOC, 2015b; Fernandes et al., 2017). Especially, regarding the comparison with olive oil, the FA profile is very similar, including the minor FA; actually, the only meaningful difference can be noticed in the palmitoleic acid content in the Chile A sample. Technologically, the high amount of monounsaturated FA is closely related to the high oxidative stability of oils, since oils with high amounts of polyunsaturated FA are more susceptible to an oxidation process due to the number of double bonds available to react with oxygen. Nutritionally, the consumption of oleic acid has been reported as healthy, supported by the positive effects of the consumption of avocado oil, as already cited in the introduction (Lerman-Gaber et al., 1994, Ortiz-Avila et al., 2013; Carvajal-Zarrabal et al., 2014).

The FA distribution in the TAG is another important identity parameter related to the saponifiable fraction of lipids. The experimental TAG profiles are described in Table 2. For all samples, the ECN48 and ECN46 TAG groups were the most abundant ones. The Brazil sample had the most different profile due to the high amount of palmitic and palmitoleic acids. The TAG profile of the Brazil sample was very particular, with the peak corresponding to $\mathrm{POO}+\mathrm{SOL}$ as the biggest one $(21.14 \pm 0.98 \%)$, followed by OOO+PLP+PoPP 


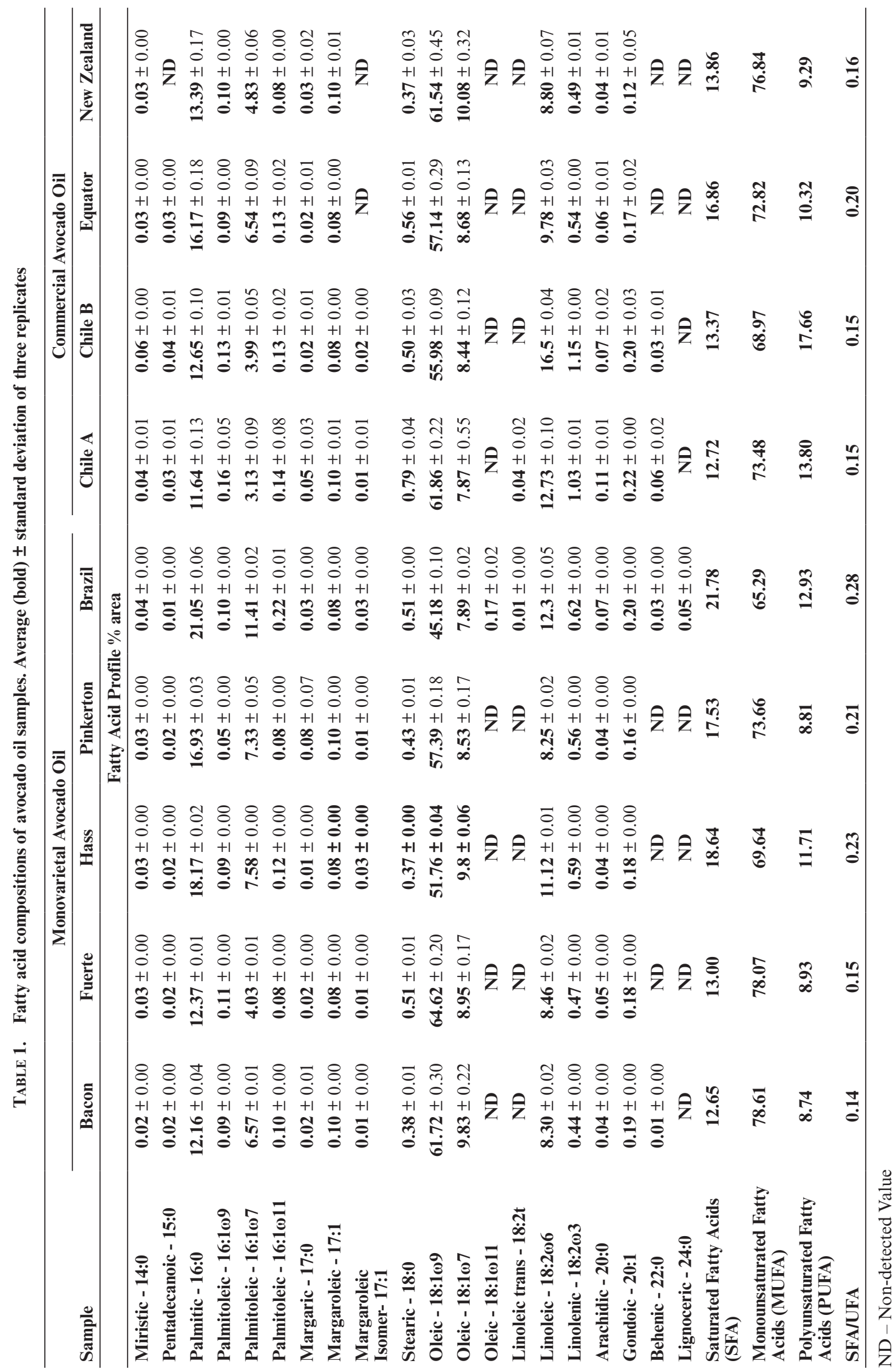




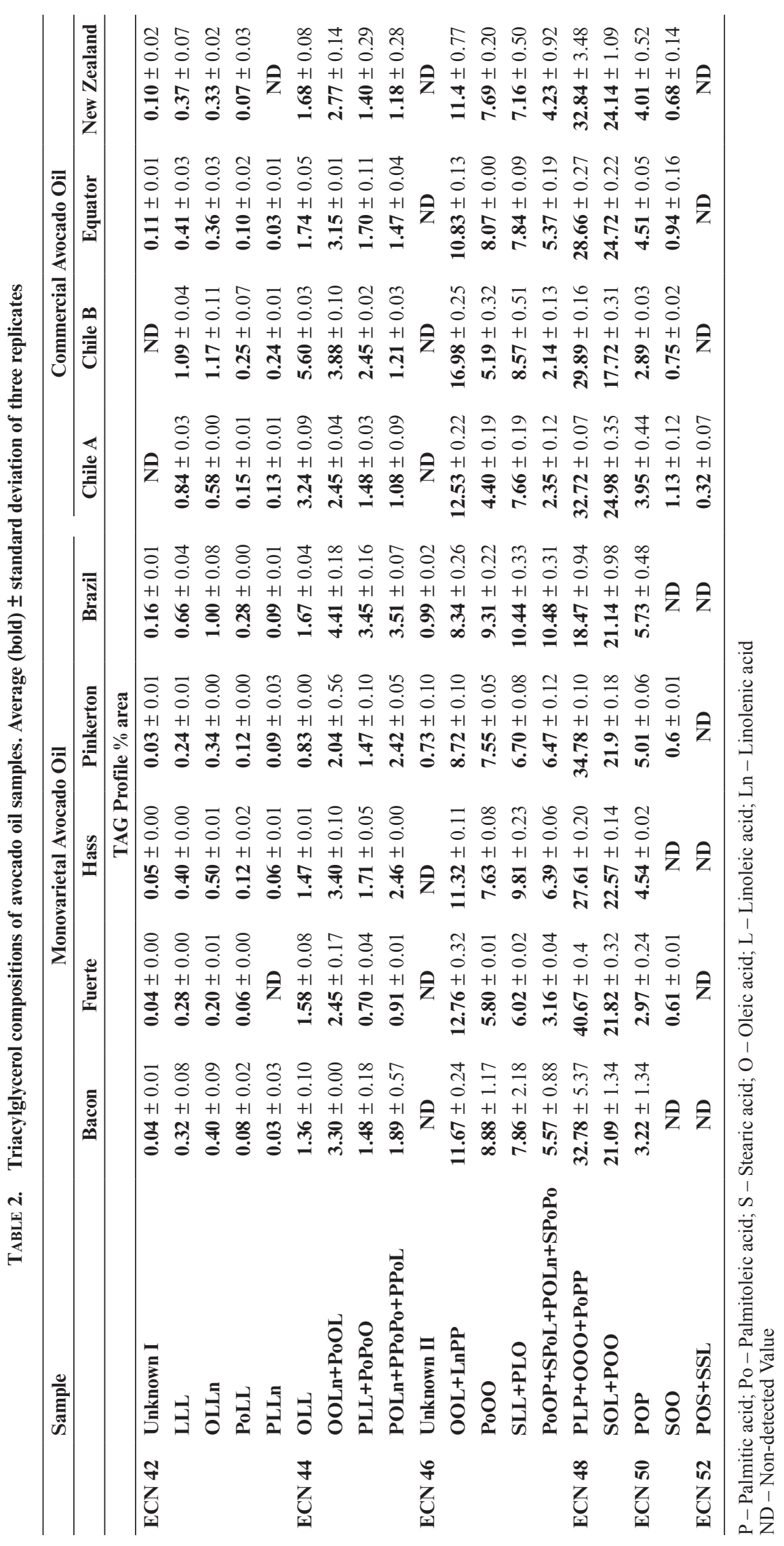

Grasas Aceites 69 (2), April-June 2018, e256. ISSN-L: 0017-3495 https://doi.org/10.3989/gya.0110181 
$(18.47 \pm 0.94 \%)$ and in almost equal amounts of PoOP+SPoL+POLn+SPoPo $(10.48 \pm 0.31 \%)$ and SLL+PLO (10.44 $\pm 0.33 \%)$. For the other samples, the highest peak matches OOO+PLP+PoPP and ranged from $27.61 \pm 0.20 \%$ in Hass to $40.67 \pm 0.40 \%$ in Fuerte. Other important TAG were POO+SOL, which varied between $17.72 \pm 0.31 \%$ in Chile $\mathrm{B}$ and $24.98 \pm 0.35 \%$ in Chile A, and OLL + LnPP which ranged from $8.72 \pm 0.10 \%$ to $16.98 \pm 0.25 \%$. Although the Brazil sample was the most different one, its TAG profile was closer than those to those given by Hierro et al. (1992). Finally, the TAG profiles of samples other than those from the Brazil cultivar were very close to the olive oil TAG profile described by Moreda et al. (2003); as explained above, the presence of monounsaturated fatty acid in the main TAG molecules is responsible for the high oxidative stability of avocado oil.

\subsection{Minor compounds, unsaponifiable components}

Minor compounds are widely related to fat and oil identity and they are normally found in the unsaponifiable matter (Gómez-Coca et al., 2015). Sterols are one of the most representative class of unsaponifiable components and among them, desmethyl-sterols are the most commonly analyzed. However, in this work methyl- and dimethyl-sterols were also determined (Table 3). The total amount of desmethyl-sterols in avocado oil was very high, ranging from $3828.78 \pm 11.67 \mathrm{mg} \cdot \mathrm{kg}^{-1}$ in Chile A to $7611.88 \pm 0.91 \mathrm{mg} \cdot \mathrm{kg}^{-1}$ in Hass. When the profile of desmethyl-sterols was evaluated, $\beta$-sitosterol was the most abundant one with concentrations between $80.56 \pm 0.08 \%$ (Fuerte) and $86.03 \pm 0.03 \%$ (New Zealand). The second-most important sterol was $\Delta 5$-avenasterol $(4.36 \pm 0.03-9.26 \pm 0.03 \%)$, followed by campesterol (3.71 $\pm 0.01-6.09 \pm 0.03 \%)$. The amount of the major sterols was very close to that cited for avocado oil. However, the detailed composition shown in Tables 3 and 4 has not been reported before (Salgado et al., 2008; Gómez-Coca et al., 2015; Woolf et al., 2009). The amount of desmethylsterols (phytosterols) in the case of vegetable oils was very high even when compared to olive oil (around $1500 \mathrm{mg} \cdot \mathrm{kg}^{-1}$ ). The consumption of phytosterols is related to the reduction in the absorption of cholesterol and, consequently, to the prevention of cardiovascular diseases, contributing in this way to the beneficial effects of avocado oil intake (OrtizAvila et al., 2013; Carvajal-Zarrabal et al., 2014).

Regarding methyl-sterols, Pinkerton was the sample with the highest concentration (1091.66 \pm 2.84 $\left.\mathrm{mg} \cdot \mathrm{kg}^{-1}\right)$; whereas Chile A had the lowest one (287.98 $\left.\pm 7.32 \mathrm{mg} \cdot \mathrm{kg}^{-1}\right)$ among all the analyzed oils. Within this class, citrostadienol was the predominant compound ranging from $71.21 \pm 0.21 \%$ (Ecuador) to $83.04 \pm 0.23 \%$ (Bacon). Dimethyl-sterols, the most variable class of compounds within the sterol group, were present at values from $39.68 \pm 1.56 \mathrm{mg} \cdot \mathrm{kg}^{-1}$ in Chile B to $545.33 \pm 25.84 \mathrm{mg} \cdot \mathrm{kg}^{-1}$ in Pinkerton. Bacon was the only sample in which 24-methylen cycloartenol was relevant $(74.47 \pm 0.58 \%)$ since in the other cases, cycloartenol was always the main compound oscillating between $50.77 \pm 0.62 \%$ in Pinkerton and $70.43 \pm 3.24 \%$ in Chile B.

The health effects of squalene have already been described and they come mainly from olive oil consumption (Newmark, 1997). In the samples under study, squalene concentrations were between $190.52 \pm 5.40 \mathrm{mg} \cdot \mathrm{kg}^{-1}$ (New Zealand) and $1366.64 \pm 6.52 \mathrm{mg} \cdot \mathrm{kg}^{-1}$ (Fuerte). From the data in Table 4, it can be deduced that the amount of squalene in avocado oil is comparable to corn and olive oil. Therefore, the high amount of squalene in avocado oil possibly has an important contribution to its healthy effects (Gómez-Coca et al., 2015).

Phytol and geranylgeraniol are primary alkenols with terpenic skeletons. Total concentrations were below $100 \mathrm{mg} \cdot \mathrm{kg}^{-1}$ for all samples. Chile B oil was the sample with the highest amount, 92.36 \pm 16.46 $\mathrm{mg} \cdot \mathrm{kg}^{-1}$, and the New Zealand oil sample contained the lowest, at $41.68 \pm 2.04 \mathrm{mg} \cdot \mathrm{kg}^{-1}$. Geranylgeraniol was normally the compound in the highest proportion among all of them $(54.97 \pm 3.14 \%$ $79.44 \pm 2.47 \%$ ), except for the case of Chile A oil, in which the proportion of the two compounds were almost the same.

The aliphatic alcohol profile is dominated by molecules with even carbon numbers, such as $\mathrm{C} 22-\mathrm{OH}, \mathrm{C} 24-\mathrm{OH}, \mathrm{C} 26-\mathrm{OH}$, and $\mathrm{C} 28-\mathrm{OH}$. In the Bacon, Brazil, Fuerte, Hass, New Zealand and Pinkerton cultivars the main alcohol was $\mathrm{C} 22-\mathrm{OH}$ (31.59 $\pm 0.09 \%-43.75 \pm 6.35 \%$; whereas in Chile $\mathrm{A}$ and $\mathrm{B}$ samples, $\mathrm{C} 26-\mathrm{OH}$ was the main one $(21.34 \pm 4.18 \%$ and $31.59 \pm 1.36 \%$, respectively). Only in the Ecuador sample, $\mathrm{C} 28-\mathrm{OH}$ stood out among the others $(27.28 \pm 6.79 \%)$.

The presence and the concentration of tocopherols are closely related to both identity and quality since these molecules have antioxidant activity and may indicate the resistance of oil to oxidation as well as the fact of having been exposed to oxidation conditions. The total amount of tocopherols (Table 4) in commercial samples was very low when compared to mono-varietal oils. In the case of the Ecuador sample, tocopherols were not possible to quantify and in other commercial samples the concentration was below $50 \mathrm{mg} \cdot \mathrm{kg}^{-1}$. However, in the mono-varietal samples, the tocopherol concentration ranged from $107.39 \pm 0.71 \mathrm{mg} \cdot \mathrm{kg}^{-1}$ to $141.50 \pm 4.15 \mathrm{mg} \cdot \mathrm{kg}^{-1}$. This fact can be related to a long storage period or to bad storage conditions in the grocery, taking into account that tocopherols are natural antioxidants of vegetable oils and that they are the first molecules to be consumed during the oxidation process, which suggests a certain degree of oxidation in this sample. 
Chemical characterization of commercial and single-variety avocado oils $\bullet 9$

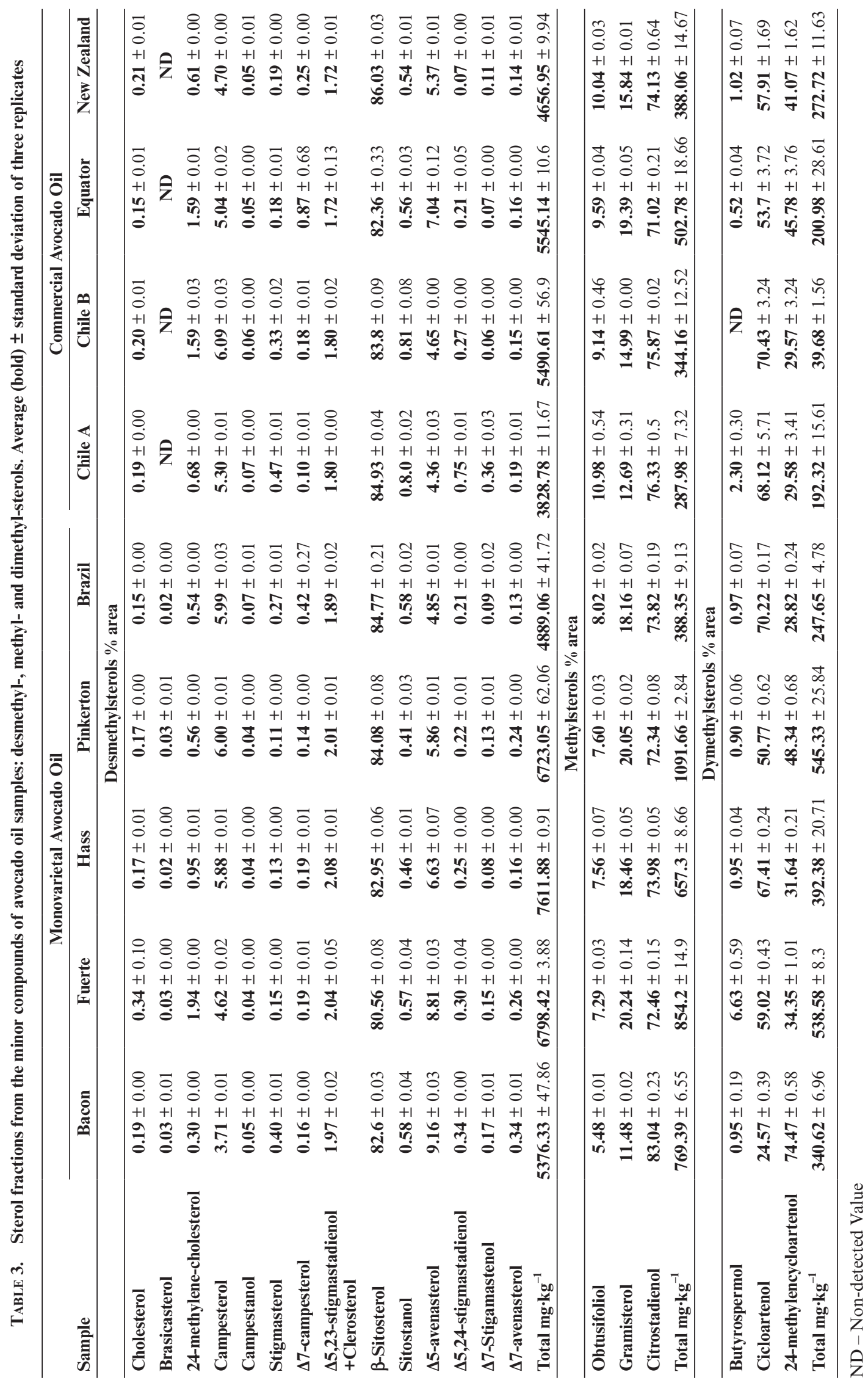

Grasas Aceites 69 (2), April-June 2018, e256. ISSN-L: 0017-3495 https://doi.org/10.3989/gya.0110181 


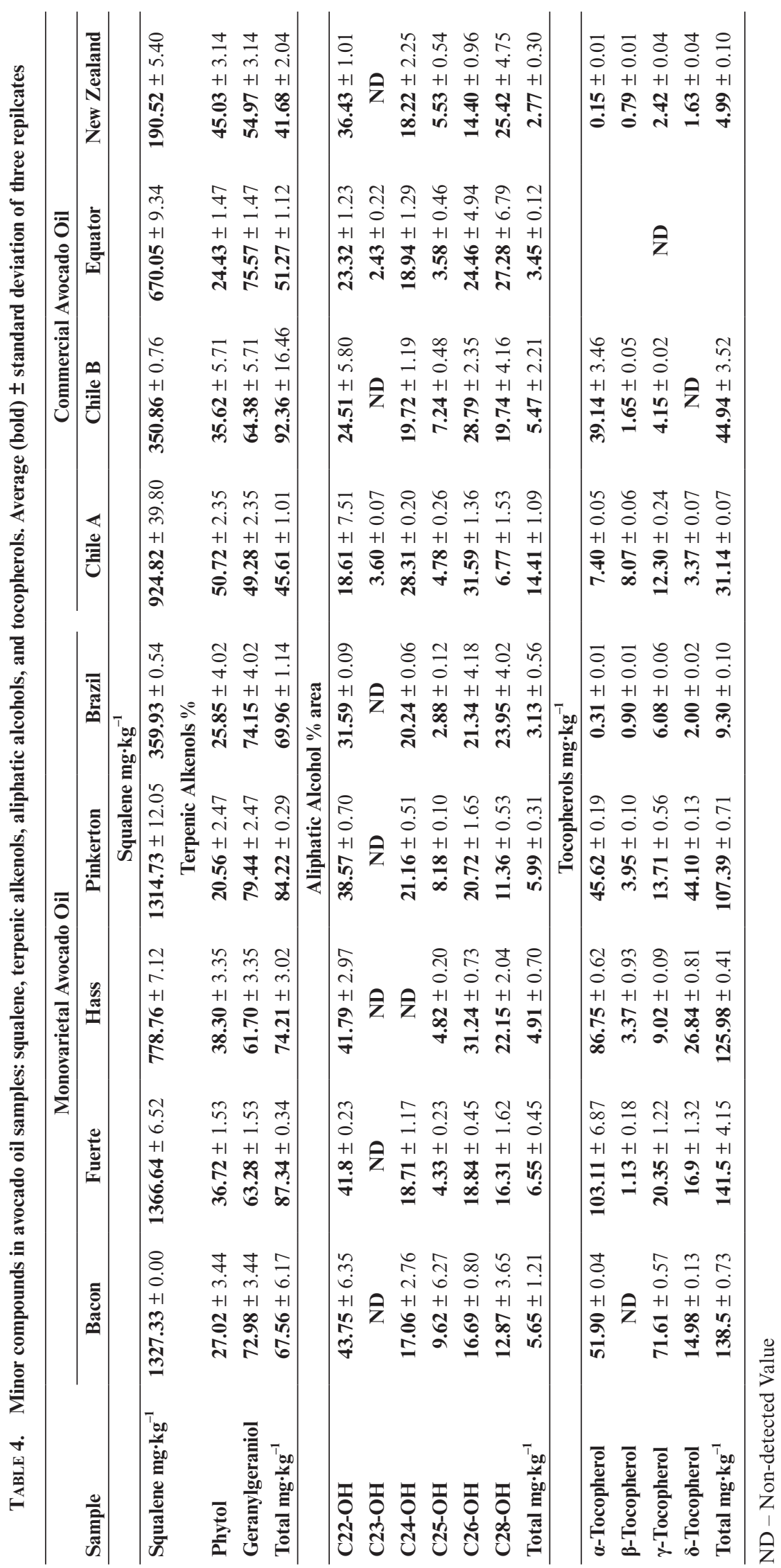




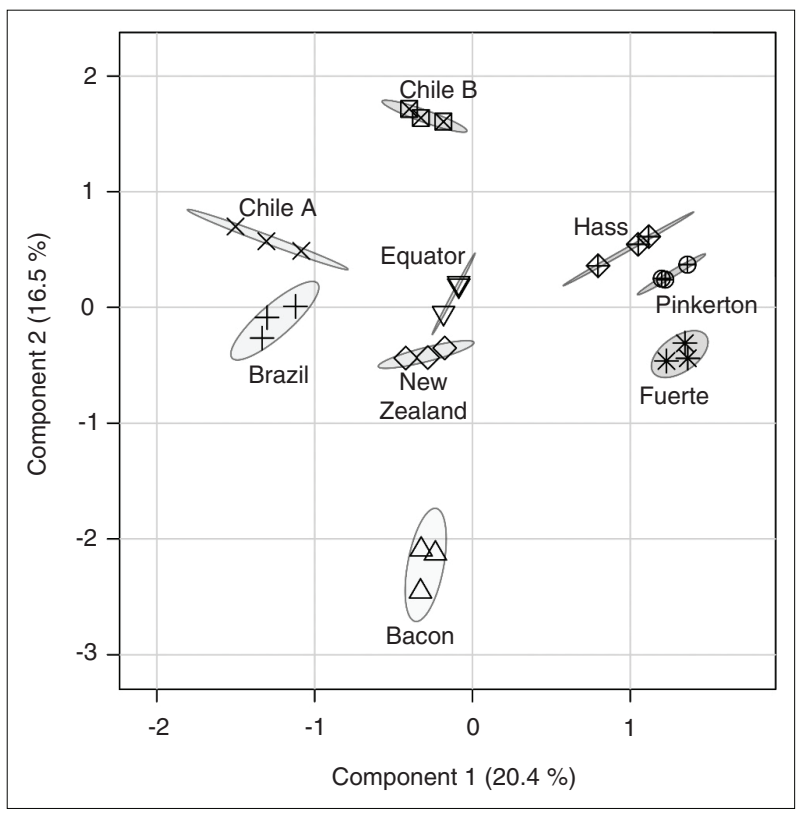

Figure 1. Partial least square discriminant analysis plot for all analyzed samples with $95 \%$ confidence region, $\mathrm{C} 1 \times \mathrm{C} 2$

Generally, $\alpha$-tocopherol was the main species found, except in Bacon, where $\gamma$-tocopherol was the most abundant one. Tocotrienols were not found in these samples.

To the best of our knowledge, these approaches to avocado oil characterization (detailed characterization of major and minor compounds from the same sample) have never been published, which makes both the election of relevant characterization parameters and the subsequent discussions difficult. In this line, we performed a PLS-DA test in order to find relationships among samples and to determine which parameters were more important to establish these relationships.

After the statistical analysis described in the Material and Methods section, the distribution graphic based on components 1 and 2 was chosen, and explained more than $35 \%$ of the data variance. As Figure 1 shows, the sum of components 1 and 2 clearly separates all the samples with a $95 \%$ confidence region. Among the commercial oil samples, they are clearly located between Component 2 (C2) $-1 ; 2$ and Component 1 (C1) -2;0. The mono-varietal oils from Hass, Pinkerton and Bacon are located between $\mathrm{C} 2-1 ; 2$ and $\mathrm{C} 1$ 0;1, thus $\mathrm{C} 1$ separates commercial oil samples from the mono-varietal Hass, Pinkerton and Fuerte oils. On the other hand, Bacon is the only mono-varietal oil sample in the negative zone of $\mathrm{C} 1$ and the only sample in the $\mathrm{C} 2<-1$ zone.

The VIP scores in Figure 2 show the ten most significant features for grouping the samples, as well as the weight of each variable on the plotted distribution of the samples. Looking at the characteristics already described in the chemical composition,

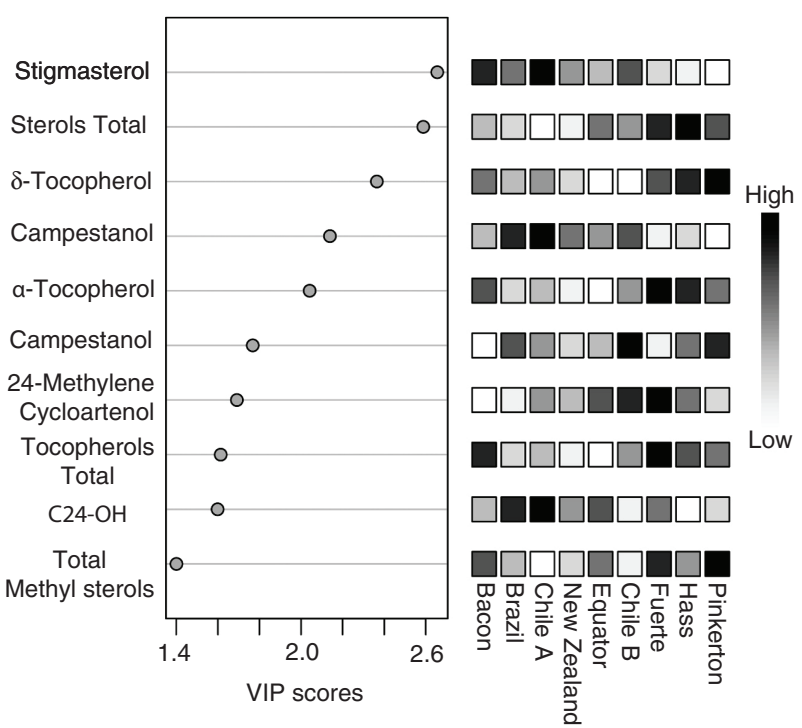

FIGURE 2. Scores of variable importance in the projection of Component 1

they match the features selected in the VIP scores. More specifically, we can see that minor compounds had a great importance on the establishment of the distinguish plot (Figure 1). Sterol composition was the most representative feature. Stigmasterol was very important for the commercial samples. However, campestanol and the total amount of sterols were significant for the mono-varietal oils. The same importance was noticed for tocopherols in the mono-varietal oils; their presence was key to this characterization. Other minor compounds such as methyl-sterols and aliphatic alcohols are represented in the VIP score plot.

It is essential to note that Figures 1 and 2 are graphical means and summarized representation of all the information described in Tables 1-4. In other words, we can see that the full characterization has great potential for the differentiation of oil samples from different varieties, as well as commercial samples. With this, we encourage future studies in order to examine oils from different crops, growing places, ripening stage and shelf life to create a mathematical model to support the establishment of universal standards for avocado oil.

\section{CONCLUSIONS}

Avocado oil can be considered mainly a monounsaturated oil, with oleic acid as the main FA. The TAG composition is also dominated by oleic acid. The presence of $\omega 7, \omega 9$ and $\omega 11$ isomers of oleic and palmitoleic acids in avocado oil were described for the first time.

Desmethyl-sterols were determined, with $\beta$-sitosterol as the main molecule we found. The squalene concentrations were higher in Bacon, 
Fuerte and Pinkerton oils, than in Hass and commercial oils; those oils may be suggested as potential squalene sources. Tocopherols (but not tocotrienols) were also found, and were mainly $\alpha$ and $\gamma$-tocopherol.

Minor compounds like methyl- and dimethylsterols, terpenic alkenols, and aliphatic alcohols were described for the first time in this work.

From the global data, it was also possible to distinguish which features were more important for sample differentiation. PLS-DA and its VIP scores revealed statistical differences among the samples, mainly related to commercial oils. Such differences should be taken into account for establishing future regulatory laws.

\section{ACKNOWLEDGMENTS}

We thank the Instituto de Hortofruticultura Subtropical y Mediterránea La Mayora (IHSMCSIC, Málaga-Spain) for providing the avocado samples, the Coordination for the Improvement of Higher Education Personnel (CAPES, Brazil) and the National Council for Scientific and Technological Development (CNPq, Brazil) for the scholarship and financial assistance.

\section{REFERENCES}

Ashworth VETM, Clegg MT. 2003. Microsatellite markers in avocado (Persea americana Mill.): genealogical relationships cultivated avocado genotypes. J. Hered. 94, 407-415. https://doi.org/10.1093/jhered/esg076

Botha BM, McCrindle RI. 2003 Supercritical fluid extraction of avocado oil. South African Avocado Growers Association Yearbook 26, 27-36.

Carvajal-Zarrabal O, Nolasco-Hipolito C, Aguilar-Uscanga MG, Melo-Santiesteban G, Hayward-Jones PM, BarradasDermitz DM. 2014. Avocado Oil Supplementation Modifies Cardiovascular Risk Profile Markers in a Rat Model of Sucrose-Induced Metabolic Changes. Dis. Markers 2014, 1-8. https://doi.org/10.1155/2014/386425

FAOSTAT (Food and Agriculture Organization of United Nations, Statistic Division). Production/Crops/Avocado 2014. URL http://faostat.fao.org/. Accessed 31.08.17.

Fernandes GD, Gómez-Coca RB, Pérez-Camino, MC, Moreda W, Barrera-Arellano D. 2017. Chemical characterization of major and minor compounds of nut oils: almond, hazelnut, and pecan nut. Journal of Chemistry 2017, 1-11. https://doi.org/10.1155/2017/2609549

Freitas SP, Yahya QR, Lago RCA. 1998. Economics analysis of enzymatic extraction of avocado oil. Riv. Ital. Sostanze Grasse 75, 15-19.

Gómez-Coca RB, Pérez-Camino MC, Moreda W. 2015. Analysis of Neutral Lipids: Unsaponifiable in Nollet L, Toldrá F, (Eds) Handbook of Food Analysis, 3rd ed. CRC Press: Boca Raton, 459-491.

Hierro MT, Tomás MC, Fernández-Martín F, Santa-María G. 1992. Determination of the triclyceride compositon of avocado oil by high-peerformance liquid chromatography using a light-scattering detector. J. Chromatogr. 607, 329338. https://doi.org/10.1016/0021-9673(92)87092-M

IOC. 2001. Determination of stigmastadienes in vegetable oils. COI/ T.20/ Doc. no. 11.

IOC. 2013. Determination of the composition and content of sterols and triterpene dialcohols by capillary column gas chromatography. COI/ T.20/ Doc. no. 30.
IOC. 2015. Determination of aliphatic alcohols content by capillary gas chromatography. COI/ T.20/ Doc. no. 26.

IOC. 2015b. Trade standard applying to olive oils and olivepomace oils. COI/ T.15/ NC No 3/Rev. 8.

IUPAC. 1987. Standard Method 2.301. Standard methods for the analysis of oils, fats and derivatives. Preparation of fatty acid methylester. Blackwell Scientific: Oxford, Great Britain.

IUPAC. 1987. Standard Method 2.302. Standard methods for the analysis of oils, fats and derivatives. Determination of FAMES by capillary GC Blackwell Scientific: Oxford, Great Britain.

IUPAC. 1987. Standard Method 2.432. Standard methods for the analysis of oils, fats and derivatives. Determination of tocopherol and tocotrienols in vegetable oils and fats by HPLC. Blackwell Scientific: Oxford, Great Britain.

Lanzón A, Guinda A, Albi T, De La Osa C. 1995. Método rápido para la determinación de escualeno en aceites vegetales. Grasas Aceites 46, 276-278. https://doi.org/10.3989/ gya.1995.v46.i4-5.937

Lerman-Garber I, Ichazo-Cerro S, Zamora-Gonzáles J. 1994. Effect of a high monounsaturated fat diet enriched with avocado in NIDDM patients. Diabetes Care 17, 311-315. https://doi.org/10.2337/diacare.17.4.311

Martínez-Nieto L, Barranco-Barranco R, Moreno-Romero MV. 1992. Extracción de aceite de aguacate: un experimento industrial. Grasas Aceites 43, 11-15. https://doi. org/10.3989/gya.1992.v43.i1.1190

Mohameed S, Sharon D, Kaufman D, Lahav E, Hillel J, Degani C, Lavi U. 1997. Genetic relationships within avocado (Persea americana Mill) cultivars and between Persea species. Theor. Appl. Genet. 94, 279-286. https://doi. org/10.1007/s001220050411

Moreda W, Pérez-Camino MC, Cert A. 2003. Improved method for the determination of triacylglycerols in olive oils by high performance liquid chromatography. Grasas Aceites 54, 175-179. https://doi.org/10.3989/gya.2003.v54.i2.262

Moreno AO, Dorantes L, Galíndez J, Guzmán RI. 2003. Effect of different extraction methods on fatty acids, volatile compounds, and physical and chemical properties of avocado (Persea americana Mill.) oil. J. Agric. Food Chem. 51, 2216-1121. https://doi.org/10.1021/jf0207934

Newmark HL. 1997. Squalene, olive oil, and cancer risk: a review and hypothesis. Cancer Epidemiol. Biomarkers Prev. 6, 1101-1103.

Ortiz MA, Dorantes AL, Galíndez MJ, Cárdenas E. 2004. Effect of a novel oil extraction method on avocado (Persea americana Mill) pulp microstructure. Plant Foods Hum. Nutr. 58, 11-14. https://doi.org/10.1007/s11130-004-0032-3

Ortiz-Avila O, Sámano-García CA, Calderón-Cortés E, PérezHernández IH, Mejía-Zepeda R, Rodríguez-Orozco AR, Saavedra-Molina A, Cortés-Rojo C. 2013. Dietary avocado oil supplementation attenuates the alterations induced by type I diabetes and oxidative stress in electron transfer at the complex II-complex III segment of the electron transport chain in rat kidney mitochondria. J. Bioenerg. Biomembr. 45, 271-287. https://doi.org/10. 1007/s10863-013-9502-3

Platt KA, Thomson WW. 1992. Idioblast oil cells of avocado: Distribution, isolation, ultrastructure, histochemistry, and biochemistry. Int. J. Plant Sci. 153, 301-310. https://doi. org/10.1086/297033

Rueda A, Seiquer I, Olalla M, Giménez R, Lara L, CabreraVique C. 2014. Characterization of fatty acid profile of argan oil and other edible vegetable oils by gas chromatography and discriminant analysis. J. Chem. 2014, 1-8. https://doi.org/10.1155/2014/843908

Rueda A, Samaniego-Sánchez C, Olalla M, Giménez R, Cabrera-Vique C, Seiquer I, Lara L. 2016. Combination of analytical and chemometric methods as a useful tool for the characterization of extra virgin argan oil and other edible virgin oils. Role of polyphenols and tocopherols. J. AOAC Int. 99, 489-494.

Salgado JM, Danieli F, Regitano-D'arce MAB, Frias A, Mansi DN. 2008. O óleo de abacate (Persea americana Mill) como matéria-prima para a indústria alimentícia. Ciênc. 
Tecnol. Aliment. 28 (Supl.), 20-26. https://doi.org/10.1590/ S0101-20612008000500004

Tango JS, Carvalho CRL, Soares NB. 2004. Physical and chemical characterization of avocado fruits aiming its potential for oil extraction. Rev. Bras. Frutic. 26, 17-23. https://doi. org/10.1590/S0100-29452004000100007

Tango JS, Costa SI, Antunes AJ, Figueiredo IB. 1972 Composition du fruit et de l'huile de différentes variétés d'avocats cultivés dans l'Etat de São Paulo. Fruits 27, 143-146.

Werman MJ, Neeman I. 1987. Avocado oil production and chemical characteristics. J. Am. Oil Chem. Soc. 64, 229232. https://doi.org/10.1007/BF02542007
Wong M, Requejo-Jackman C, Woolf A. 2010. What is unrefined, extra virgin cold-pressed avocado oil? URL http://www. aocs.org/Membership/FreeCover.cfm?ItemNumber=1099 Accessed 06/03/15.

Woolf A, Wong M, Eyres L, McGhie T, Lund C, Olsson S, Wang Y, Bulley C, Wang M, Friel E, Requejo-Jackman C. 2009. Avocado oil. From cosmetic to culinary oil. in Moreau R, Kamal-Eldin A (Eds.) Gourmet and Health-Promoting Specialty Oils, 1st ed. AOCS: Urbana, 73-125.

Xia J, Mandal R, Sinelnikov I, Broadhurst D, Wishart DS. 2012. MetaboAnalyst 2.0 - a comprehensive server for metaboomic data analysis. Nucl. Acids Res. 40, W127-W133. https://doi.org/10.1093/nar/gks374 